\title{
Microbial amino acid synthesis and utilization in rats: the role of coprophagy
}

\author{
BY DAVID TORRALLARDONA*, C. IAN HARRIS \\ AND MALCOLM F. FULLER
}

The Rowett Research Institute, Greenburn Road, Bucksburn, Aberdeen AB2 9SB

(Received 14 September 1995 - Revised 10 January 1996-Accepted 23 January 1996)

\begin{abstract}
Four rats were housed in cages with mesh floors; another four rats were housed in tubular anticoprophagy cages, in which they could not turn round to reach their own faeces. Both groups were fed for $6 \mathrm{~d}$ on a low-protein diet containing fermentable carbohydrates and ${ }^{15} \mathrm{NH}_{4} \mathrm{Cl}$. At the end of the experiment the rats were killed and their carcasses were homogenized, lysine was isolated by ionexchange chromatography and its ${ }^{15} \mathrm{~N}$ enrichment measured by isotope-ratio mass spectrometry. The ${ }^{15} \mathrm{~N}$ enrichment in the lysine of the microbial fraction of faeces and the total amount of lysine in the body were also determined in order to estimate the amount of microbial lysine absorbed. The ${ }^{15} \mathrm{~N}$ enrichment in body lysine of non-coprophagic rats was not different from that previously measured in rats given unlabelled $\mathrm{NH}_{4} \mathrm{Cl}$, but in coprophagic rats it was significantly higher. The daily absorption of microbial lysine by the coprophagic rats accounted for 20.7 (SE 2.55 ) $\mathrm{mg} / \mathrm{kg}$ body weight ${ }^{0.75}$, but was only 0.5 (SE 1.04$) \mathrm{mg} / \mathrm{kg}$ body weight ${ }^{075}$ for the non-coprophagic rats. This value was not significantly different from zero. The utilization of microbial amino acids via coprophagy resulted in a higher weight gain (adjusted for intake) in the coprophagic group (15.5 g/6 d) than in the non-coprophagic rats (3.1 g/6 d). It was concluded that, in rats, the utilization of microbial lysine occurred exclusively via coprophagy.

Coprophagy: Gastrointestinal microflora: Amino acid requirements
\end{abstract}

In the previous paper (Torrallardona et al. 1996) it was reported that rats are able to absorb nutritionally significant quantities of amino acids originating from their gastrointestinal microflora. That estimate, however, was based on the assumption that the ${ }^{15} \mathrm{~N}$ enrichment of the microbial amino acids being absorbed was that of the faecal microbes. This microbial lysine, however, could have been absorbed in one or both of two ways. The first is direct absorption, by which microbial amino acids could have been synthesized and absorbed during one passage of the gastrointestinal tract. The second is indirect, via coprophagy, in which faecal bacteria would be subjected to the digestive processes in the upper gastrointestinal tract as shown by Midvedt \& Gustafsson (1981).

It is well recognized that rats practice coprophagy; Barnes et al. (1957) concluded that rats normally ingest $50-65 \%$ of the faeces they produce. This amount might be even higher if rats are fed on a nutritionally-deficient diet and they can obtain the deficient nutrient from the faeces (Barnes et al. 1957; Barnes \& Fiala, 1959).

The aim of the present study was to establish how much of the amino acid absorption found previously was due to coprophagy and how much was due to direct absorption. Preliminary results of the present study have been published previously in abstract form (Torrallardona et al. 1994a).

* Present Address: IRTA-Centre de Mas Bové, Apartat 415, 43280 Reus, Spain. 


\section{MATERIALS AND METHODS}

\section{Animals and housing}

Eight male Hooded Lister (Rowett strain) rats of about $200 \mathrm{~g}$ body weight were used. The animals had been reared on a well-balanced commercial diet. Throughout the adaptation period all the animals were housed in Perspex cages with wire-mesh floors. The movement of the animals was not restricted, and they had direct access to their own faeces.

During the experimental period the animals were divided into two groups of four animals. One group (coprophagic) was kept in the Perspex cages; the other group (noncoprophagic) was moved into tubular anti-coprophagy cages (Fig. 1) similar to those used by Rolls (1970) and Metta et al. (1961). The inter-connecting tubes of the anti-coprophagy cages were constructed from galvanized-steel mesh (12 mm squares). The corners were soldered and the inside top and sides lined with polyvinylchloride (PVC) elbow bends. These PVC pieces provided a constant diameter in the corners. One of the straight segments was also lined with a PVC tube, in order to provide a resting area for the rats in which they would not feel exposed. The bottom of each PVC piece was removed, so that faeces would fall freely through the wire mesh. Food was supplied ad libitum in a glass jar fitted into the front of the cage and water was supplied from a bottle attached to the side of the cage. The cages were suspended from a frame. Rats placed in these cages could move comfortably, but they could not turn round to reach their own faeces, which fell easily through the $12 \mathrm{~mm}$ mesh floor.

\section{Diets}

The diets were the same as those described in the previous paper (Torrallardona et al. 1996) except that $50 \mathrm{~g}$ lactalbumin $/ \mathrm{kg}$ was included in order to maintain the rats' body weight. It was found that even a small loss in body weight by the rats housed in the anticoprophagy cages resulted in their being able to turn so that the cages were no longer effective in preventing coprophagy. The diets (Table 1) contained fermentable carbohydrates and $\mathrm{NH}_{4} \mathrm{Cl}$ which was either unlabelled or labelled with ${ }^{15} \mathrm{~N}$.

\section{Experimental periods and design}

The experiment consisted of an adaptation period of $8 \mathrm{~d}$ and an experimental period of $6 \mathrm{~d}$. During the adaptation period all the animals were housed in the Perspex cages and were gradually transferred from the stock diet to the unlabelled experimental diet. The animals of the non-coprophagic group were adapted to the anti-coprophagy cages for the last $24 \mathrm{~h}$ of this period. During the experimental period both groups of animals were given the ${ }^{15} \mathrm{~N}$ labelled experimental diet.

\section{Sampling and analysis}

During the experimental period the animals were weighed daily and their feed consumption was recorded. Faeces were collected daily, pooled individually for each rat and frozen. At the end of the experimental period the animals were killed, the gastrointestinal tract was removed (in order to avoid contamination of the carcass with microbial amino acids), emptied and weighed, and the carcass was frozen until analysed. ${ }^{15} \mathrm{~N}$ enrichments of lysine in the carcass and in the microbial fraction were determined as described previously (Torrallardona et al. 1996). The lysine content of the body of the rats was also measured. The ${ }^{15} \mathrm{~N}$ enrichment of lysine measured in the control group (fed unlabelled $\mathrm{NH}_{4} \mathrm{Cl}$ ) of the previous experiment (Torrallardona et al. 1996) was taken as the natural abundance.

\section{Calculations and statistical analysis}

The absorption of microbial lysine $\left(A_{M L y s} ; \mathrm{mg}\right)$ was estimated as:

$$
A_{M L y s}=\left(E_{B L y s} \times C_{B L y s}\right) / E_{M L y s}
$$




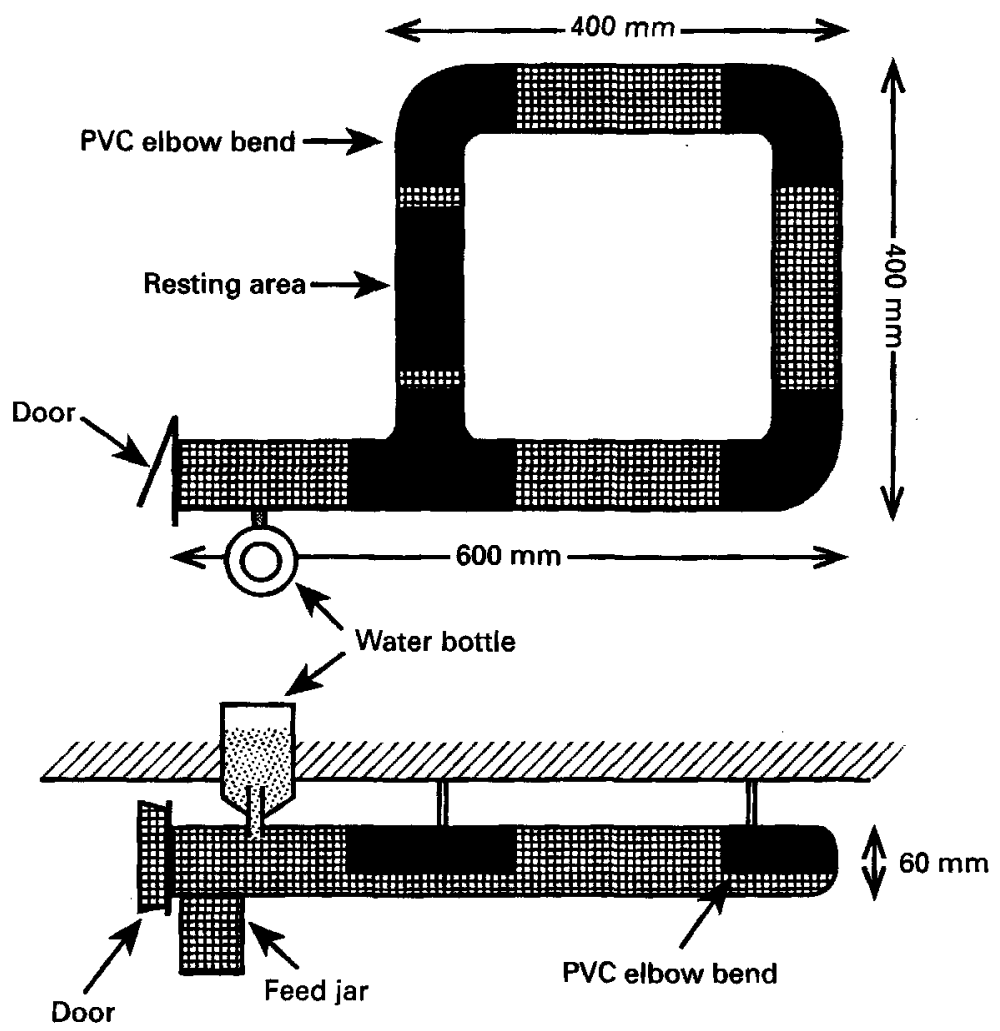

Fig. 1. Tubular anti-coprophagy cage for $200 \mathrm{~g}$ rats.

Table 1. Diet composition $(\mathrm{g} / \mathrm{kg})$

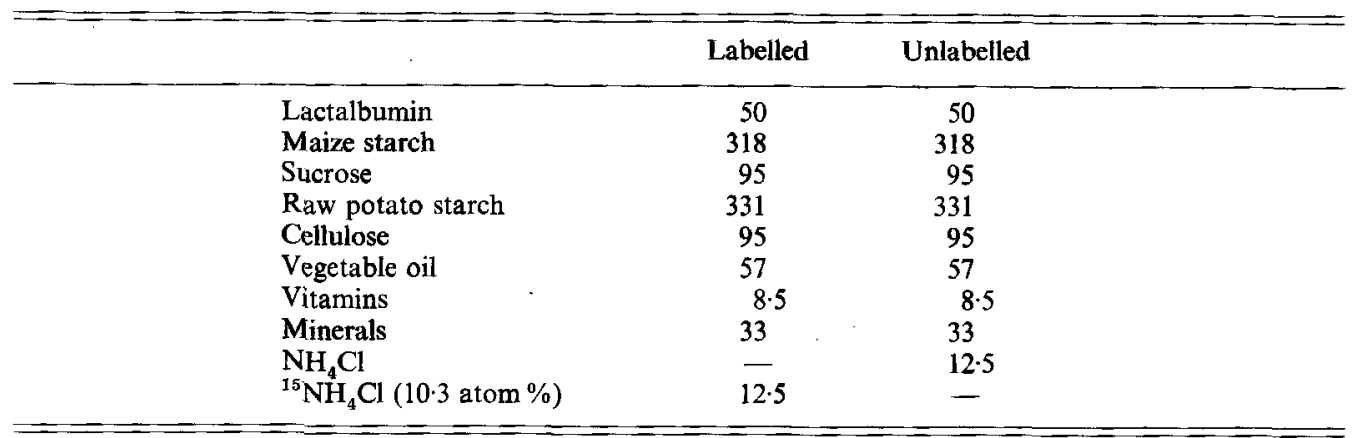

where $E_{B L y s}$ was the enrichment of body lysine (atom \% excess), $C_{B L y s}$ was the total content of lysine in the body $(\mathrm{mg})$, and $E_{M L y s}$ was the enrichment of microbial lysine (atom \% excess).

The statistical significance of the differences between the treatments in ${ }^{15} \mathrm{~N}$ enrichments of lysine, body weights and feed intakes were assessed using Student's $t$ test. The differences in weight gain and microbial lysine enrichments were also assessed by analysis of covariance using feed intake as the covariate. The statistical tests were applied using the statistical analysis package MINITAB (Minitab Inc., 1989). 


\section{RESULTS}

\section{Feed intake and body-weight changes}

The total ${ }^{15} \mathrm{~N}$ doses consumed by the non-coprophagic and coprophagic rats were 46.0 (SE $3 \cdot 21$ ) and 39.2 (SE 2.12) $\mathrm{mg}$ respectively (i.e. 151.4 (SE 9.05) and 126.9 (SE 5.97) $\mathrm{mg} / \mathrm{kg}$ body weight ${ }^{0.75}$ ).

There were no statistically significant differences in feed intake $(P=0 \cdot 127)$, weight gain $(P=0.164)$ or in initial $(P=0.480)$ or final $(P=0.364)$ body weights between the two groups of animals. However, feed intake had a significant effect on weight gain $(P=0.019$; Fig. 2); when weight gain was adjusted for differences in intake by analysis of covariance, statistically significant differences were observed $(P=0.009)$ between the two groups of rats, showing a significantly better utilization of the diet by the coprophagic animals (Table 2).

\section{${ }^{15} \mathrm{~N}$ enrichment in body lysine}

The ${ }^{15} \mathrm{~N}$ enrichment of body lysine for non-coprophagic rats was not significantly different $(P=0.57)$ from that measured for the control group (fed on unlabelled diet) of the previous experiment (0.0000 (SE 0.00009); Torrallardona et al. 1996). The ${ }^{15} \mathrm{~N}$ enrichment of lysine for the coprophagic group, however, was significantly $(P=0.0002)$ higher than that for the control group (Table 3).

\section{${ }^{15} \mathrm{~N}$ enrichment in microbial lysine}

Both groups showed a substantial ${ }^{15} \mathrm{~N}$ enrichment of the lysine in the microbial fraction of faeces (Table 3 ), which was significantly higher $(P=0.0065)$ for the non-coprophagic group. This difference was not related to their higher feed intake (Table 2), since, when microbial lysine enrichments were compared by analysis of covariance (using intake as covariate), no significant effect $(P=0.495)$ of intake on microbial lysine enrichment was found. Prevention of coprophagy, however, had a statistically significant effect $(P=0.015)$. The effects of feed intake and coprophagy on microbial lysine enrichment are illustrated in Fig. 3.

\section{Microbial lysine absorption}

The absorption of microbial lysine (Table 3) was estimated by dividing the total amount of labelled lysine in the body by the enrichment of lysine in the microbial fraction of faeces as described previously. The estimated amount of microbial lysine absorbed by the coprophagic rats was 6.4 (SE 0.75$) \mathrm{mg} / \mathrm{d}$ or 20.7 (SE 2.55$) \mathrm{mg} / \mathrm{kg}$ body weight ${ }^{0.75}$ per $\mathrm{d}$. The non-coprophagic rats absorbed 0.1 (SE 0.32$) \mathrm{mg} / \mathrm{d}$ or 0.5 (SE 1.04) $\mathrm{mg} / \mathrm{kg}$ body weight $\mathrm{t}^{0.75}$ per $d$. This was not significantly different from zero.

The amino acid composition of the microbial fraction of faeces was also determined. Assuming that all the amino acids in microbial protein were absorbed to a similar extent as lysine, we have estimated, by simple proportionality, the absorption of the other amino acids (Table 4).

\section{DISCUSSION}

The results showed that only coprophagic rats were able to incorporate ${ }^{15} \mathrm{~N}$ into body lysine, suggesting that, in the rat, microbial lysine absorption occurs exclusively via coprophagy. This supports the hypothesis that the large intestine of non-ruminant animals, where most microbial activity takes place, does not normally absorb amino acids directly from the lumen (Zebrowska, 1973; Just et al. 1981; Wünsche et al. 1984; Schmitz et al. 1991). 


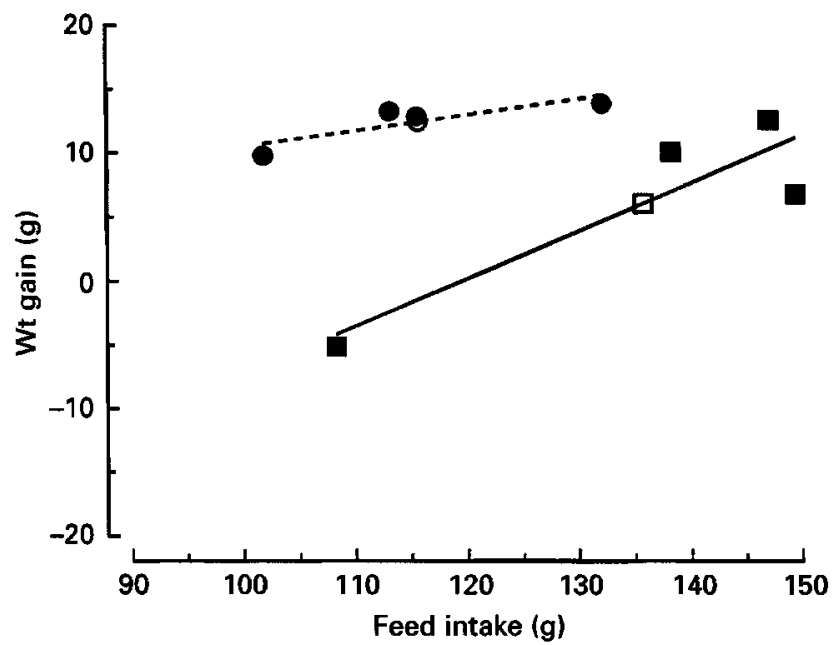

Fig. 2. Relationship between feed intake and weight gain in coprophagic $(O)$ and non-coprophagic ( $\square$ ) rats fed on diet containing ${ }^{14} \mathrm{NH}_{4} \mathrm{Cl}$. For coprophagic animals: $r^{2} 0 \cdot 600, P=0 \cdot 225$; for non-coprophagic rats: $r^{2} 0.810$, $P=0 \cdot 100$. $(\mathrm{O}, \square)$, Mean values. For details of diets and procedures, see Table 1 and pp. $702-703$.

Table 2. Weights and feed intakes of coprophagic and non-coprophagic rats* (Mean values with their standard errors for four rats)

\begin{tabular}{|c|c|c|c|c|c|c|}
\hline & & $\begin{array}{l}\text { Initial wt } \\
(\mathrm{g})\end{array}$ & $\begin{array}{l}\text { Final wt } \\
\text { (g) }\end{array}$ & $\begin{array}{l}\text { Wt gain } \\
(\mathrm{g} / 6 \mathrm{~d})\end{array}$ & $\begin{array}{l}\text { Feed intake } \\
\qquad(\mathrm{g} / 6 \mathrm{~d})\end{array}$ & $\begin{array}{l}\text { Wt gain } \dagger \\
(\mathrm{g} / 6 \mathrm{~d})\end{array}$ \\
\hline \multicolumn{2}{|c|}{ Non-coprophagic: Mean } & $197 \cdot 7$ & $203 \cdot 8$ & $6 \cdot 1$ & $135 \cdot 8$ & $3 \cdot 1^{\mathrm{a}}$ \\
\hline & SE & 0.64 & 3.66 & 3.92 & $9 \cdot 48$ & \\
\hline \multirow[t]{2}{*}{ Coprophagic: } & Mean & 196.0 & $208 \cdot 4$ & $12 \cdot 5$ & $115 \cdot 7$ & $15 \cdot 5^{\mathrm{b}}$ \\
\hline & SE & $2 \cdot 20$ & 2.99 & 0.92 & $6 \cdot 26$ & \\
\hline
\end{tabular}

a, b Mean values with unlike superscript letters were significantly different $(P<0 \cdot 01)$.

* For details of diets and experimental procedures, see Table 1 and p. 702.

$\dagger$ Adjusted for intake.

The lack of enrichment in the body lysine of non-coprophagic rats could not be explained by differences in the enrichment of microbial lysine, since both groups showed substantial ${ }^{15} \mathrm{~N}$ incorporation into the lysine of the microbial fraction of faeces. In fact, noncoprophagic rats (despite having no enrichment in body lysine) produced faeces with a higher ${ }^{15} \mathrm{~N}$ enrichment of microbial lysine than the coprophagic animals. This difference did not result from the higher feed intake of non-coprophagic rats; there was no relationship between intake and ${ }^{15} \mathrm{~N}$ enrichment in body lysine (Fig. 3). A possible explanation is that in coprophagic animals the dietary ${ }^{15} \mathrm{~N}$ was diluted by unlabelled $\mathrm{N}$ from faeces, resulting in a lower ${ }^{15} \mathrm{~N}$ enrichment of both the ingested $\mathrm{N}$ and the microbial amino acids synthesized from it.

Because microbial amino acids were absorbed only after coprophagy, it was appropriate, in estimating microbial lysine absorption, to use as the precursor the ${ }^{15} \mathrm{~N}$ enrichment of the lysine in the microbial fraction of faeces pooled over the whole experiment, as that represented the enrichment of the microbial amino acids being absorbed.

The rate of lysine absorption estimated in the coprophagic animals $(20.7 \mathrm{mg} / \mathrm{kg}$ body weight $\left.^{0.75}\right)$ was very similar to that estimated in the conventional rats $(21.3 \mathrm{mg} / \mathrm{kg}$ body 
Table $3 .{ }^{15} \mathrm{~N}$ enrichments of lysine (atom \% excess) and microbial lysine absorption in coprophagic and non-coprophagic rats fed on diet containing ${ }^{15} \mathrm{NH}_{4} \mathrm{Cl}^{*}$

\begin{tabular}{|c|c|c|c|c|c|}
\hline & \multicolumn{2}{|c|}{ Lysine ${ }^{15} \mathrm{~N}$ enrichment } & \multirow{2}{*}{$\begin{array}{c}\text { Body lysine } \\
\text { content } \\
\text { (g) }\end{array}$} & \multicolumn{2}{|r|}{ Lysine absorbed } \\
\hline & Body & Microbial & & $\mathrm{mg} / \mathrm{d}$ & $\mathrm{mg} / \mathrm{kg}$ body $\mathrm{wt}^{0.75}$ per $\mathrm{d}$ \\
\hline \multicolumn{6}{|c|}{ Non-coprophagic } \\
\hline Rat 1 & 0.0002 & 0.7538 & $2 \cdot 52$ & $0 \cdot 13$ & 0.43 \\
\hline Rat 2 & -0.0006 & 0.5757 & $2 \cdot 76$ & $-0 \cdot 46$ & -0.150 \\
\hline Rat 3 & -0.0002 & 0.6091 & 2.45 & $-0 \cdot 12$ & -0.39 \\
\hline Rat 4 & 0.0018 & 0.7853 & $2 \cdot 70$ & 1.05 & $3 \cdot 36$ \\
\hline Mean & $0.0003^{a}$ & $0.6810^{c}$ & $2 \cdot 61$ & $0 \cdot 15^{\mathrm{a}}$ & $0.47^{\mathrm{a}}$ \\
\hline $\mathrm{SE}$ & 0.00053 & 0.0520 & 0.073 & 0.322 & 1.04 \\
\hline \multicolumn{6}{|c|}{ Coprophagic } \\
\hline Rat 5 & $0 \cdot 0045$ & 0.4727 & $2 \cdot 61$ & $4 \cdot 16$ & $13 \cdot 36$ \\
\hline Rat 6 & 0.0064 & 0.4394 & $2 \cdot 90$ & $7 \cdot 06$ & $22 \cdot 49$ \\
\hline Rat 7 & 0.0069 & 0.4372 & $2 \cdot 58$ & $6 \cdot 80$ & $21 \cdot 97$ \\
\hline Rat 8 & 0.0086 & 0.4954 & $2 \cdot 58$ & $7 \cdot 49$ & $25 \cdot 07$ \\
\hline Mean & $0 \cdot 0066^{b}$ & $0.4612^{d}$ & $2 \cdot 67$ & $6 \cdot 38^{b}$ & $20 \cdot 72^{\mathrm{b}}$ \\
\hline $\mathrm{SE}$ & 0.00084 & $0 \cdot 0140$ & 0.078 & 0.753 & 2.55 \\
\hline
\end{tabular}

a,b,e, d Values in the same column with different superscript letters were significantly different: ${ }^{\mathbf{a}, \mathbf{b}} P<0.001$, ${ }^{\mathrm{c}, \mathrm{d}} P<0.01$

* For details of diets and experimental procedures, see Table 1 and pp. 702-703.

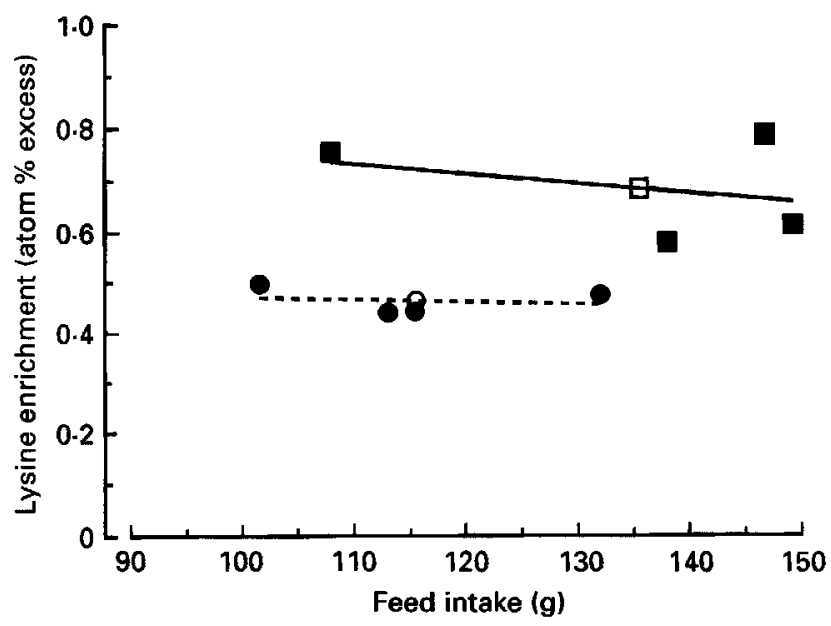

Fig. 3. Relationship between feed intake and ${ }^{15} \mathrm{~N}$ enrichments in faecal microbial lysine of coprophagic $(\boldsymbol{O})$ and non-coprophagic ( $\square$ ) rats fed on diet containing ${ }^{14} \mathrm{NH}_{4} \mathrm{Cl}$. For coprophagic animals: $r^{2} 0.045, P=0.650$; for noncoprophagic rats: $r^{2} 0 \cdot 123, P=0 \cdot 788,(O, \square)$, Mean values.

weight ${ }^{0.75}$ ) described in the previous paper (Torrallardona et al. 1996). It seems that the inclusion of $50 \mathrm{~g}$ lactalbumin $/ \mathrm{kg}$ in the diet did not affect the amount of microbial lysine being absorbed. However, other dietary differences, especially the amount of fermentable carbohydrates, could affect the amount of microbial lysine absorbed. This is supported by the observation (Torrallardona, 1994) that in a rat given a large amount of raw potato starch $(671 \mathrm{~g} / \mathrm{kg}$ diet) the estimated daily absorption of microbial lysine was $36 \mathrm{mg} / \mathrm{kg}$ body weight ${ }^{0 \cdot 75}$. 
Table 4. Amino acid composition of the microbial fraction of faeces of coprophagic rats and their estimated rate of microbial amino acid absorption together with estimates of essential amino acid requirements for maintenance*

(Mean values with their standard errors for four rats)

\begin{tabular}{|c|c|c|c|c|c|c|}
\hline & \multirow{2}{*}{\multicolumn{2}{|c|}{$\begin{array}{c}\text { Microbial } \\
\text { composition } \\
\text { (g/100 g lysine) }\end{array}$}} & \multicolumn{3}{|c|}{$\begin{array}{c}\text { Predicted } \\
\text { amino acid absorption }\end{array}$} & \multirow{3}{*}{$\begin{array}{c}\text { Maintenance } \\
\text { requirements } \dagger \\
\left(\mathrm{mg} / \mathrm{kg} \text { body } \mathrm{wt}^{0.75} \text { per } \mathrm{d}\right)\end{array}$} \\
\hline & & & \multicolumn{2}{|c|}{$\mathrm{mg} / \mathrm{d}$} & \multirow{2}{*}{$\begin{array}{l}\mathrm{mg} / \mathrm{kg} \\
\text { body } \mathrm{wt}^{0 \cdot 75} \\
\text { per } \mathrm{d}\end{array}$} & \\
\hline & Mean & SE & Mean & SE & & \\
\hline Aspartic acid & $157 \cdot 1$ & 6.52 & $10 \cdot 1$ & $1 \cdot 35$ & $32 \cdot 6$ & - \\
\hline Threonine & 76.0 & 3.74 & 4.9 & 0.68 & 15.7 & $53 \cdot 1$ \\
\hline Serine & $59 \cdot 2$ & $4 \cdot 58$ & $3 \cdot 8$ & 0.61 & $12 \cdot 3$ & - \\
\hline Glutamic acid & 185.6 & $6 \cdot 05$ & 11.9 & 1.58 & $38 \cdot 5$ & $\ldots$ \\
\hline Glycine & 73.9 & $2 \cdot 17$ & $4 \cdot 7$ & 0.60 & $15 \cdot 3$ & - \\
\hline Alanine & $126 \cdot 2$ & 3.46 & $8 \cdot 1$ & 1.07 & $26 \cdot 1$ & - \\
\hline Valine & $81 \cdot 5$ & 3.00 & $5 \cdot 2$ & 0.70 & 16.9 & $67 \cdot 1$ \\
\hline Isoleucine & $71 \cdot 3$ & 2.05 & $4 \cdot 6$ & 0.58 & 14.8 & $90 \cdot 4$ \\
\hline Leucine & $100 \cdot 5$ & 3.49 & 6.4 & 0.84 & $20 \cdot 8$ & $53 \cdot 1$ \\
\hline Tyrosine & $59 \cdot 6$ & $2 \cdot 89$ & $3 \cdot 8$ & 0.52 & $12 \cdot 3$ & - \\
\hline Phenylalanine & $60 \cdot 1$ & $2 \cdot 25$ & $3 \cdot 8$ & 0.50 & $12 \cdot 5$ & $54 \cdot 5 \ddagger$ \\
\hline Proline & $46 \cdot 6$ & 1.87 & $3 \cdot 0$ & 0.40 & $9 \cdot 7$ & - \\
\hline Lysine & 100 & & $6 \cdot 4$ & 0.75 & $20 \cdot 7$ & $32 \cdot 2$ \\
\hline Histidine & 23.8 & 0.73 & $1 \cdot 5$ & 0.19 & $4 \cdot 9$ & $23 \cdot 5$ \\
\hline Arginine & 63.6 & 1.96 & $4 \cdot 0$ & 0.44 & $13 \cdot 2$ & - \\
\hline
\end{tabular}

* For details of diets and experimental procedures, see Table 1 and pp. 702-703.

$\dagger$ From National Research Council (1995).

$\ddagger$ Phenylalanine + tyrosine.

To estimate the contribution that this source of amino acids makes to the animal's requirements we have compared our estimates of microbial amino acid uptake with the maintenance requirements of rats. Estimates of these quantities vary widely (Benditt et al. 1950; Smith \& Johnson, 1967; Said \& Hegsted, 1970; Dreyer, 1975; Neale \& Waterlow, 1974). For the purpose of illustrating the general magnitude of the microbial contribution we have chosen the values collated by the National Research Council (1995), which are given in Table 4. By this comparison the gastrointestinal microflora supply, via coprophagy, is between one-sixth and two-thirds of the animal's maintenance amino acid needs; the highest value is for lysine, the one amino acid for which we estimated the absorption directly.

These experiments, and those which we have also carried out with pigs (Torrallardona et al. 1993, 1994 b, 1995), give cause to consider what is meant by a 'requirement' and the methods used to estimate this. It is normally considered that, for non-ruminant animals, the diet is the only source of the indispensable amino acids and estimates of requirements have been made on that basis. Thus, amino acid requirements for maintenance are conventionally estimated as the smallest amount supplied, in an otherwise nutritionally-adequate diet, which allows $\mathrm{N}$ equilibrium to be maintained. The present results, however, lead to the view, discussed by Torrallardona (1994) and Jackson (1995), that it may be necessary to distinguish between dietary requirements and metabolic requirements; the metabolic requirements may be met partially by the diet and partially by microbial synthesis. Thus, requirements estimated from dietary intake alone could result in an underestimation of the metabolic requirement, which is the rate at which an amino acid must be absorbed in order 
to prevent body $\mathrm{N}$ loss. This is supported by the observation of Bender (1960) that adult rats could be maintained for over 6 months on a lysine-free diet. This observation can be interpreted not as evidence that the animals' lysine requirement was zero but that its metabolic requirement could be met entirely by coprophagy.

It is of interest that Neale \& Waterlow (1974) estimated the lysine and leucine requirements of rats by direct isotopic measurements (i.e. 'metabolic' maintenance requirements). They concluded that the lysine and leucine requirements of rats were 136 and $80 \mathrm{mg} / \mathrm{kg}$ body weight ${ }^{075}$ per $\mathrm{d}$ respectively. These values are much higher than the National Research Council (1995) estimates (32 and $53 \mathrm{mg} / \mathrm{kg}$ body weight ${ }^{0.75}$ per d), adding further weight to the suggestion that conventional 'dietary' requirements may be less than 'metabolic' requirements.

The authors wish to acknowledge the assistance of $E$. Milne in mass spectrometric analysis and support from the Scottish Office Agriculture and Fisheries Department. D.T. was supported by a fellowship from the INIA, Spain.

\section{REFERENCES}

Barnes, R. H. \& Fiala, G. (1959). Effects of the prevention of coprophagy in the rat. VI. Vitamin K. Journal of Nutrition 68, 603-614.

Barnes, R. H., Fiala, G., McGhee, B. \& Brown, A. (1957). Prevention of coprophagy in the rat. Journal of Nutrition 63, 489-498.

Bender, A. E. (1960). Correlation of amino acid composition with nutritive value of proteins. Clinica Chimica Acta 5, 1-5.

Benditt, E. P., Woolridge, R. L., Steffee, C. H. \& Frazier, L. E. (1950). Studies in amino acid utilization. IV. The minimum requirements of the indispensable amino acids for maintenance of the adult well-nourished male albino rat. Journal of Nutrition 40, 335-350.

Dreyer, J. J. (1975). Biological assessment of protein quality. Essential amino acid requirements of young rats in certain states of nitrogen balance. South African Medical Journal 49, 1667-1673.

Jackson, A. A. (1995). Salvage of urea-nitrogen and protein requirements. Proceedings of the Nutrition Society 54 535-547.

Just, A., Jørgensen, H. \& Fernández, J. A. (1981). The digestive capacity of the caecum-colon and the value of the nitrogen absorbed from the hind gut for protein synthesis in pigs. British Journal of Nutrition 46, 209-219.

Metta, V. C., Nash, L. \& Johnson, B. C. (1961). A tubular coprophagy-preventing cage for the rat. Journal of Nutrition 74, 473-476.

Midvedt, T. \& Gustafsson, B. E. (1981). Digestion of dead bacteria by germ-free rats. Current Microbiology 6, 13-15.

Minitab Inc. (1989). MINITAB. State College, PA: Minitab Inc.

National Research Council (1995). Nutrient Requirements of Laboratory Animals. Washington, D.C.: National Academy Press.

Neale, R. J. \& Waterlow, J. C. (1974). Critical evaluation of a method for estimating amino acid requirements for maintenance in the rat by measurement of the rate of ${ }^{14} \mathrm{C}$-labelled amino acid oxidation in vivo. British Journal of Nutrition 32, 257-272.

Rolls, B. A. (1970). Factors influencing the digestion and absorption of protein in the rat. PhD Thesis, University of Reading.

Said, A. K. \& Hegsted, D. M. (1970). Response of adult rats to low dietary levels of essential amino acids. Journal of Nutrition 100, 1363-1376.

Schmitz, M., Ahrens, F., Schön, J. \& Hagemeister, H. (1991). Amino acid absorption and its significance for protein supply in the pig. In Digestive Physiology in Pigs. Proceedings of the Vth International Symposium on Digestive Physiology in Pigs, pp. 85-87 [M. W. A. Verstegen, J. Huisman and L. A. den Hartog, editors]. Wageningen: Pudoc.

Smith, E. B. \& Johnson, B. C. (1967). Studies of amino acid requirements of adult rats. British Journal of Nutrition 21, 17-27.

Torrallardona, D. (1994). The contribution of the gastrointestinal microflora to the amino acid requirements of non-ruminants. PhD Thesis, University of Aberdeen.

Torrallardona, D., Harris, C. I., Coates, M. E. \& Fuller, M. F. (1996). Microbial amino acid synthesis and utilization in rats: incorporation of ${ }^{15} \mathrm{~N}$ from ${ }^{15} \mathrm{NH}_{4} \mathrm{Cl}$ into lysine in the tissues of germ-free and conventional rats. British Journal of Nutrition 76, 689-700.

Torrallardona, D., Harris, C. I., Milne, E. \& Fuller, M. F. (1993). Contribution of intestinal microflora to lysine requirements in nonruminants. Proceedings of the Nutrition Society 52, 153A. 
Torrallardona, D., Harris, C. I., Milne, E. \& Fuller, M. F. (1994a). Role of coprophagy in the utilization of microbial lysine by rats. Proceedings of the Nutrition Society 53, 109 A.

Torrallardona, D., Harris, C. I., Milne, E. \& Fuller, M. F. (1994b). The contribution of intestinal microflora to amino acid requirements in pigs. In Proceedings of the VIth International Symposium on Digestive Physiology in Pigs. European Association of Animal Production Publication no. 80, pp. 245-248 [W. B. Souffrant and H. Hagemeister, editors]. Dummerstorf: Forschungsinstitut für die Biologie landwirtschaftlicher Nutztiere.

Torrallardona, D., Harris, C. I., Milne, E. \& Fuller, M. F. (1995). Site of absorption of lysine synthesis by the gastrointestinal microflora of pigs. In Proceedings of the VII International Symposium on Protein Metabolism and Nutrition. European Association of Animal Production Publication no. 81, pp. 369-371 [A. F. Nunes, A. V. Portugal, J. P. Costa and J. R. Ribeiro, editors]. Santarém, Portugal: Estaçao Zootécnica Nacional.

Wünsche, J., Hennig, U., Meinl, M. \& Bock, H.-D. (1984). Amino acid absorption from the caecum of growing pigs. In Proceedings of the VI International Symposium on Amino Acids, pp. 158-167 [T. Zebrowska, L. Buraczewska, S. Buraczewska, J. Kowalczyk and B. Pastuzewska, editors]. Warsaw: Polish Scientific Publishers.

Zebrowska, T. (1973). Digestion and absorption of nitrogenous compounds in the large intestine of pigs. Roczniki Nauk Rolniczych 95B, 85-90. 